\title{
Loss of High Affinity Cardiac Beta Adrenergic Receptors in Dogs with Heart Failure
}

\author{
Dorothy E. Vatner, Stephen F. Vatner, Alan M. Fujii, and Charles J. Homcy \\ Department of Medicine, Harvard Medical School, Massachusetts General Hospital, and Brigham and Women's Hospital, Boston, \\ Massachusetts 02114; the Cardiac Unit, and Childrens' Service, Massachusetts General Hospital, Boston, Massachusetts 02114; and the \\ New England Regional Primate Research Center, Southborough, Massachusetts 01772
}

\begin{abstract}
We studied the alterations in myocardial $\beta$-adrenergic receptoradenylate cyclase activity and muscarinic receptor density in a canine model of left ventricular (LV) failure. $L V$ failure was characterized by a doubling of $\mathrm{LV}$ weight/body weight ratio $(3.3 \pm 0.1$ to $6.9 \pm 0.4 \mathrm{~g} / \mathrm{kg})$ and an elevation of $\mathrm{LV}$ end-diastolic pressure, $32 \pm 4.5 \mathrm{mmHg}$, compared with $7.7 \pm 0.6 \mathrm{mmHg}$ in normal dogs. Despite a $44 \%$ increase in receptor density as measured by antagonist binding studies with $\left[{ }^{3} \mathbf{H}\right]$ dihydroalprenolol, there was a twofold decrease in receptor affinity, i.e., an increase in the dissociation constant $\left(K_{d}\right)(5.6 \pm 0.7$ to $12 \pm 1.6 \mathrm{nM})$ in heart failure. Agonist displacement of $\left[{ }^{3} \mathbf{H}\right]$ dihydroalprenolol binding with isoproterenol in the presence and absence of 5 '-guanylylimidodiphosphate [Gpp(NH)p] demonstrated a striking loss of high affinity binding sites in heart failure (51 \pm 16 to $11 \pm 5 \%)$. $\beta$-Adrenergic receptor-mediated stimulation of adenylate cyclase and maximal stimulation with $\mathrm{Gpp}(\mathrm{NH})$ p or sodium fluoride was reduced in heart failure. There was a concomitant marked, $P$ $<0.01$, reduction in muscarinic receptor density $(242 \pm 19$ vs. $111 \pm 20 \mathrm{fmol} / \mathrm{mg}$ ). Thus, while muscarinic receptor density fell, $\beta$-adrenergic receptor density actually increased in $L V$ failure. However, a larger portion of the $\beta$-adrenergic receptors are not functionally coupled to the GTP-stimulatory protein $\left(N_{\mathrm{s}}\right)$, as evidenced by a decrease in the fraction of receptors that bind agonist with high affinity.
\end{abstract}

\section{Introduction}

Several disorders of autonomic cardiovascular control have been described in experimental animals and patients with heart failure (1-3). It is conceivable that the mechanism of altered autonomic control of the heart involves changes in receptor regulation. While little is known regarding changes in muscarinic receptors, two prior studies have examined $\beta$-adrenergic receptor regulation in heart failure, but have reported divergent results. Karliner et al. (4) found increased $\beta$-adrenergic receptor number in a guinea pig heart failure model, whereas Bristow et al. (5) found the reverse in end stage heart failure in man. It is important to note that no prior study has systematically evaluated the changes in $\beta$-adrenergic receptor density and affinity, using agonist and an-

Address reprint requests to Dr. Dorothy E. Vatner, Cellular and Molecular Research, Jackson 13, Massachusetts General Hospital, Boston, MA 02114.

Received for publication 26 March 1985 and in revised form 2 July 1985.

J. Clin. Invest.

(C) The American Society for Clinical Investigation, Inc. $0021-9738 / 85 / 12 / 2259 / 06 \quad \$ 1.00$

Volume 76, December 1985, 2259-2264 tagonist ligand binding studies in combination with measurement of adenylate cyclase activity in an experimental large mammalian model of left ventricular $(\mathrm{LV})^{1}$ failure.

The goal of this investigation was to examine $\beta$-adrenergic and muscarinic receptor regulation in dogs with pressure overload-induced LV failure. The advantages of this model are the spontaneous development of LV failure, and the gradual development of the $\mathrm{LV}$ pressure overload lesion over one year. Furthermore, not only was $\beta$-adrenergic receptor number and adenylate cyclase activity quantitated, but also receptor-cyclase coupling was examined by calculating the fraction of the receptor population in a high affinity state for agonists from isoproterenol competition curves in the presence and absence of 5'-guanylylimidodiphosphate [Gpp(NH)p].

\section{Methods}

Mongrel puppies of either sex at 7-10-wk-old were anesthetized with sodium thiamylal $(10 \mathrm{mg} / \mathrm{kg}$ ), maintained with halothane ( $1 \mathrm{vol} \%)$, and ventilated with an animal respirator (Harvard Apparatus Co., Inc., S. Natick, MA). A right thoracotomy was performed through the fourth intercostal space using sterile surgical technique. The ascending aorta above the coronary arteries was isolated and dissected free of surrounding tissue. A $1-\mathrm{cm}$ wide Teflon cuff was placed around the aorta, tightened until a thrill was palpable over the aortic arch, and the chest was closed. Nine dogs with chronic pressure overload developed LV failure spontaneously, 9 mo to $2 \mathrm{yr}$ after banding. In two dogs with stable LV hypertrophy $1 \frac{1 / 2}{\mathrm{yr}}$ after aortic banding, bilateral iliac arterial-venous shunts were surgically created under general anesthesia with sodium pentobarbital, $30 \mathrm{mg} / \mathrm{kg}$, through a midline laparotomy. In these two dogs, heart failure developed over the ensuing $2 \mathrm{wk}$. These dogs were studied and killed 1 mo later.

The data from the group with LV failure were compared with a group of 13 normal control dogs, 3 of which were sham operated littermates of the dogs with LV failure. Since the data from the sham operated dogs were similar to the data from the normal group, these two groups were combined. $\mathrm{LV}$ and arterial pressures were measured in the conscious dogs using a calibrated micromanometer catheter (Millar Instruments, Houston, TX). The catheter was introduced retrogradely into the LV using a femoral artery approach under local anesthesia with lidocaine $2 \%$. Pressures were recorded on a multichannel oscillograph. Animals used in this study were maintained in accordance with the guidelines of the Committee on Animals of the Harvard Medical School and those prepared by the Committee on Care and Use of Laboratory Animals of the Institute of Laboratory Animal Resources, National Research Council (Dept. of Health, Education and Welfare Publication No. [NIH] 78-23, revised 1978.).

Membrane preparation. After the dogs were anesthetized with sodium pentobarbital, $30 \mathrm{mg} / \mathrm{kg}$, the hearts were immediately excised and placed into iced Krebs-Ringer's solution. All subsequent procedures were carried

1. Abbreviations used in this paper: DHA, dihydroalprenolol; Gpp(NH)p, 5 '-guanylylimidodiphosphate; $K_{\mathrm{H}}$, high affinity site, $K_{\mathrm{L}}$, low affinity site; $\mathrm{LV}$, left ventricular; $\mathrm{N}_{\mathbf{s}}, \mathrm{GTP}$-stimulatory protein; $\mathrm{QNB}$, quinuclidinyl benzilate. 
out at $4^{\circ} \mathrm{C}$. Approximately $1 \mathrm{~mm}$ of epicardium and endocardium were removed with a scissors and discarded. $\mathrm{LV}$ myocardium was minced coarsely in buffer ( $250 \mathrm{mM}$ sucrose, $1 \mathrm{mM} \mathrm{MgCl} 2$, and $1 \mathrm{mM} \mathrm{KHCO}{ }_{3}$ ), and homogenized with a PT-10ST Polytron (Brinkmann Instruments Co., Westbury, NY) tissue disruptor. The homogenate was filtered through one layer of Japanese silk screen, size 14, and centrifuged in a Sorvall RC-2 (E. I. DuPont de Nemours \& Co., Inc., Sorvall Instruments Div., Newtown, CT) at $1,000 \mathrm{~g}$ for $15 \mathrm{~min}$. The supernatant was respun at $45,000 \mathrm{~g}$ for $15 \mathrm{~min}$ and the pellet was resuspended in buffer (100 $\mathrm{mM}$ Tris, $5 \mathrm{mM} \mathrm{MgCl} 2,1 \mathrm{mM}$ EDTA), using a glass homogenizer. The homogenization and $45,000 \mathrm{~g}$ centrifugation were repeated twice. The pellet was resuspended to a protein concentration of $3 \mathrm{mg} / \mathrm{ml}$ and stored in liquid nitrogen until assayed. At the time of assay, the membranes were again washed in the Tris buffer and centrifuged at 45,000 g.

Purified sarcolemma membranes were also prepared according to the method of Jones and Besch (6), from one normal dog and one dog with heart failure. This preparation involves washing out the contractile proteins and then separating the sarcolemma from other membrane proteins with a sucrose density gradient. The yield from this preparation was $10 \mathrm{mg}$ protein $/ 100 \mathrm{~g} \mathrm{LV}$.

Binding studies. All studies were performed in triplicate in the presence of $100 \mathrm{mM}$ Tris, $5 \mathrm{mM} \mathrm{MgCl}, 1 \mathrm{mM}$ EDTA, $\mathrm{pH} 7.2$.

$\beta$-Adrenergic antagonist binding studies were performed as previously described using $25 \mu \mathrm{l}\left[{ }^{3} \mathrm{H}\right]$ dihydroalprenolol $\left.\left({ }^{3} \mathrm{H}\right] \mathrm{DHA}\right), 1-40 \mathrm{nM}, 25$ $\mu \mathrm{l}$ propranolol $(10 \mu \mathrm{M})$ or buffer, and $100 \mu \mathrm{l}$ of membrane protein (100$200 \mu \mathrm{g})$. Assays were performed in triplicate, incubated at $37^{\circ} \mathrm{C}$ for 30 min, terminated by rapid filtration on Whatman GF/C filters (Whatman Chemical Separation, Clifton, NJ), and counted in $10 \mathrm{ml}$ hydrofluor for $5 \mathrm{~min}$. Specific binding was $60-70 \%(7,8)$. The data were analyzed by the "Ligand" program of Munson and Rodbard (9).

Muscarinic, cholinergic receptor binding studies were performed with increasing concentrations $(0.05-6.0 \mathrm{nM})$ of $\left[{ }^{3} \mathrm{H}\right]$ quinuclidinyl benzilate $\left(\left[{ }^{3} \mathrm{H}\right] \mathrm{QNB}\right)$, with or without atropine, $1 \mu \mathrm{M}(10,11)$. Specific binding was $>90 \%$. Assay conditions were the same as for the $\left[{ }^{3} \mathrm{H}\right] \mathrm{DHA}$ binding studies.

Agonist competition for $\left[{ }^{3} \mathrm{H}\right] \mathrm{DHA}$ binding was carried out at 16 concentrations of isoproterenol from $10^{-4}$ to $10^{-9} \mathrm{M}$ with membranes that were first washed in magnesium-free buffer $(100 \mathrm{mM}$ Tris, $10 \mathrm{mM}$ EDTA, pH 7.2), and centrifuged at $45,000 \mathrm{~g}$ for $15 \mathrm{~min}$. The pellet was resuspended in buffer ( $100 \mathrm{mM}$ Tris, $5 \mathrm{mM} \mathrm{MgCl}, 1 \mathrm{mM}$ EDTA, pH 7.2) before incubation. This procedure did not affect antagonist binding but did allow the $\mathrm{Gpp}(\mathrm{NH})$-induced shift in agonist competition curves to be more easily discerned, presumably by effectively removing endogenous guanylyl nucleotides. Isoproterenol was prepared in $0.1 \mathrm{mM}$ ascorbic acid, and kept in the dark to reduce oxidation. Incubations were carried out at $25^{\circ} \mathrm{C}$ for $40 \mathrm{~min}$.

Adenylate cyclase was assayed according to the method of Salomon et al. (12). Maximal adenylate cyclase activity was assessed by measuring cyclic AMP production in the presence of $10 \mathrm{mM}$ sodium fluoride, and $0.1 \mathrm{mM}$ isoproterenol plus $0.1 \mathrm{mM} \mathrm{Gpp}(\mathrm{NH}) \mathrm{p}$. Adenylate cyclase activity was linear, with protein concentrations from 100 to $200 \mu \mathrm{g} /$ assay tube. The magnesium concentration was chosen to optimize isoproterenolstimulated adenylate cyclase activity.

Tissue and plasma norepinephrine levels were determined according to the method of Peuler and Johnson (13). Plasma samples were drawn before killing. Tissue samples were taken from the mid-anterior free wall of the LV at the time of killing and placed in liquid nitrogen. $\mathrm{Na}^{+}, \mathrm{K}^{+}$. ATPase activity was determined according to the method of Jones and Besch (6). The protein concentrations for each membrane assay were determined by the method of Lowry et al. (14).

The affinity for isoproterenol in the presence and absence of $0.1 \mathrm{mM}$ Gpp(NH)p was calculated with the computer-assisted program, "Ligand," of Munson and Rodbard (9), which uses the F-test for best fit (15). All other data were expressed as mean value \pm SEM, and stored in a Digital computer (PDP-11/34; Digital Equipment Corp., Marlboro, MA). Statistical evaluation for the data was performed by Student's $t$ test between the two groups, i.e., control groups and groups with heart failure. A
Table I. Morphology and Hemodynamics

\begin{tabular}{lcc}
\hline & Normal $(n=13)$ & LV failure $(n=11)$ \\
\hline Body weight $(\mathrm{kg})$ & $22 \pm 1.3$ & $19 \pm 1.4$ \\
$\mathrm{LV}$ weight $(\mathrm{g})$ & $75 \pm 4.5$ & $128 \pm 10.1^{*}$ \\
LV weight $(\mathrm{g})$ /body weight $(\mathrm{kg})$ & $3.3 \pm 0.1$ & $6.9 \pm 0.4^{*}$ \\
LV systolic pressure $(\mathrm{mmHg})$ & $129 \pm 3.7$ & $254 \pm 22^{*}$ \\
LV end-diastolic pressure $(\mathrm{mmHg})$ & $7.7 \pm 0.6$ & $32 \pm 4.5^{*}$ \\
Mean arterial pressure $(\mathrm{mmHg})$ & $103 \pm 2.4$ & $89 \pm 4.2^{*}$ \\
Heart rate $($ beats/min $)$ & $95 \pm 4.9$ & $134 \pm 5.0^{*}$ \\
& & \\
\hline
\end{tabular}

$* P<0.01$ from normal values.

confidence level of $P<0.01$ was used to reduce potential errors due to multiple comparisons between groups (16).

\section{Results}

Morphologic and hemodynamic data are presented in Table I. In the dogs with LV failure, LV free wall weight per body weight as well as LV systolic and end-diastolic pressure were elevated, $P<0.01$. The doubling of LV free wall to body weight ratio indicates the severity of hypertrophy. The marked increase in LV end-diastolic pressure $(32 \pm 4.5 \mathrm{mmHg}$ vs. $7.7 \pm 0.6 \mathrm{~mm} \mathrm{Hg}$ for controls) shows that LV hypertrophy was no longer compensated, and LV failure had ensued (Table I). All dogs with LV failure had evidence of pulmonary congestion at autopsy.

$\beta$-Adrenergic receptor antagonist binding. Saturation analysis of $\left[{ }^{3} \mathrm{H}\right]$ DHA binding demonstrated a significant increase, $P$ $<0.01$, in $\beta$-adrenergic receptor concentration in the membranes prepared from the $\mathrm{LV}$ failure group $(102 \pm 8.0 \mathrm{fmol} / \mathrm{mg}$ protein, $n=11)$ compared with the normal membranes $(71 \pm 4.8 \mathrm{fmol} /$ mg protein, $n=13$ ). Specific $\left[{ }^{3} \mathrm{H}\right] \mathrm{DHA}$ binding to the myocardial membrane preparation was stereospecific and saturable, yielding a single component, linear relationship (Fig. 1) (9). In these experiments, the affinity for $\left[{ }^{3} \mathrm{H}\right] \mathrm{DHA}$ was decreased, $P<0.01$, in the LV failure dogs $\left(K_{\mathrm{d}}=12 \pm 1.6 \mathrm{nM}, n=11\right)$ as compared with the normal LV preparation $\left(K_{d}=5.6 \pm 0.7 \mathrm{nM}, n=13\right)$.

Muscarinic receptor antagonist binding. $\left[{ }^{3} \mathrm{H}\right] \mathrm{QNB}$ binding to the myocardial membranes was saturable and best characterized by a single binding site (9). Cholinergic receptor number was decreased in the LV of animals with heart failure $(111 \pm 20$

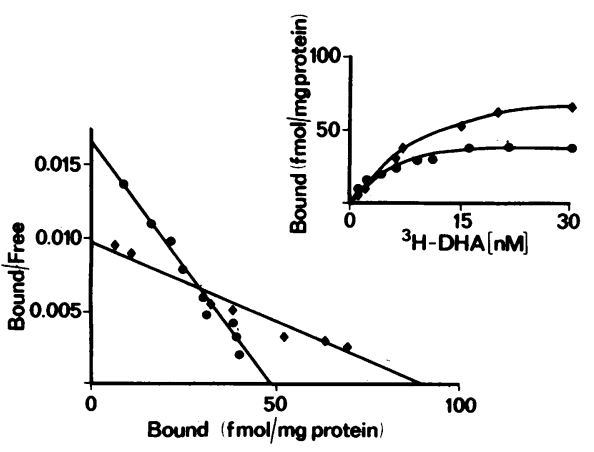

Figure 1. Scatchard analyses of $\beta$-adrenergic receptor antagonist binding to LV plasma membranes are compared in the normal heart (•) and in the heart with LV failure ( $\bullet$ ). The LV failure heart shows a lower affinity and more receptors per milligram protein than the normal LV. The insert shows a saturation plot of the same data. 


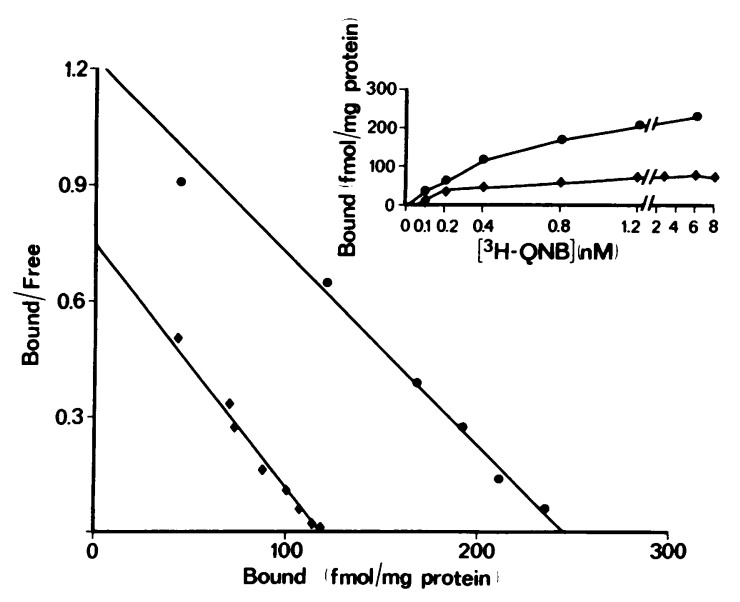

Figure 2. Scatchard analyses of muscarinic, cholinergic receptor antagonist binding to LV membranes are compared in the normal heart (•) and in the heart with LV failure ( $\bullet$ ). A decrease in receptors per milligram protein is apparent in the failing heart. The inset shows a saturation plot of the same data.

fmol/mg, $n=6, P<0.01)$ compared with the values obtained in the control group (242 $\pm 19 \mathrm{fmol} / \mathrm{mg}, n=6)$ (Fig. 2). The $K_{d}$ was $0.21 \pm 0.04 \mathrm{nM}$ in normal $\mathrm{LV}$ vs. $0.40 \pm 0.03 \mathrm{nM}$ in heart failure.

$\beta$-Adrenergic receptor agonist binding. Isoproterenol competition curves for the normal group and LV failure group can be fitted to a two-site model, i.e., a high affinity site $\left(K_{\mathrm{H}}\right)$, and a low affinity site $\left(K_{\mathrm{L}}\right)$. The $K_{\mathrm{H}}$ for normal $\mathrm{LV}$ and for LV failure groups were similar $(149 \pm 88$ vs. $130 \pm 48 \mathrm{nM})$ and $K_{\mathrm{L}}$ was $2,083 \pm 1,085$ vs. $1,439 \pm 213 \mathrm{nM}$. The major difference in $\mathrm{LV}$ failure was the loss of high affinity receptor sites (from $51 \pm 16$ to $11 \pm 5 \%$ of the receptors, $P<0.05$ ) (Table II), causing a shift to the right in the agonist binding curve in the absence of

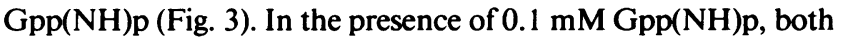
normal and LV failure curves were better described by a onesite fit $\left(K_{\mathrm{L}}\right)$, i.e., no high affinity sites. The affinity constants for the single site with $\mathrm{Gpp}(\mathrm{NH}) \mathrm{p}$ were similar for the control and LV failure hearts $(1,449 \pm 702$ vs. $1,779 \pm 125 \mathrm{nM})$.

Adenylate cyclase. Basal adenylate cyclase activity was lower in the myocardial membranes of animals with LV failure (13 \pm 3.3 $\mathrm{pmol} \mathrm{cAMP} / \mathrm{min}$ per mg protein, $n=9$ ) as compared with myocardial membranes of normal animals $(34 \pm 7.3$ pmol cAMP/ min per $\mathrm{mg}$ protein, $n=8$ ). Maximal $\beta$-receptor-mediated

Table II. Agonist Binding Studies

\begin{tabular}{lcc}
\hline & Normal $(n=9)$ & LV failure $(n=6)$ \\
\hline $\begin{array}{c}\text { Isoproterenol binding } \\
\text { affinity }(n M)\end{array}$ & & \\
$-\mathrm{Gpp}(\mathrm{NH}) \mathrm{p}$ & & \\
$K_{\mathrm{H}}$ & $149 \pm 88$ & $130 \pm 48$ \\
$K_{\mathrm{L}}$ & $2,083 \pm 1,085$ & $1,439 \pm 213$ \\
$+\mathrm{Gpp}(\mathrm{NH}) \mathrm{p}$ & & \\
$K_{\mathrm{L}}$ & $1,449 \pm 702$ & $1,779 \pm 125$ \\
High affinity receptor sites $(\%)$ & $51 \pm 16$ & $11 \pm 5^{*}$ \\
Low affinity receptor sites $(\%)$ & $49 \pm 16$ & $89 \pm 5^{*}$ \\
\hline
\end{tabular}

${ }^{*} P<0.05$ from normal values.

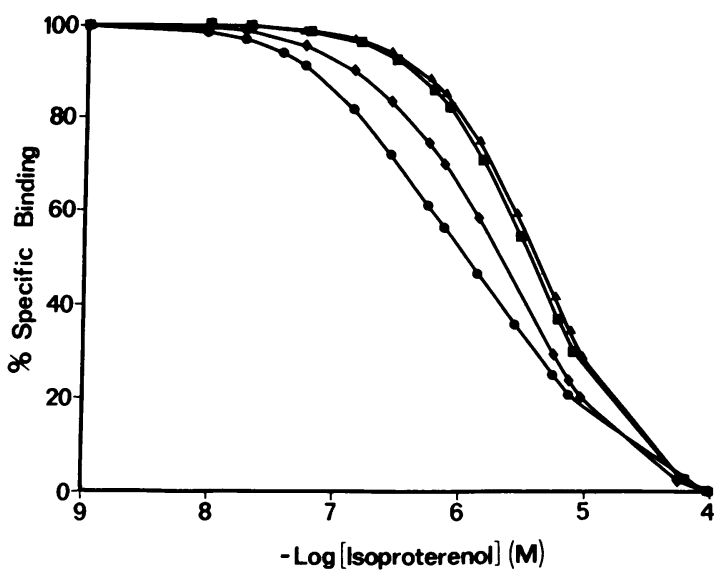

Figure 3. These curves representing $\beta$-adrenergic receptor agonist binding with isoproterenol were generated by the computer program "Ligand" from pooled data from nine normal dogs and six animals with LV failure. The data from each experiment were entered as individual displacement curves and assigned a constant value to normalize for differences in receptor number. The "Ligand" program (9) finds the best fit for all of the data. Agonist competition curves for $\left[{ }^{3} \mathrm{H}\right] \mathrm{DHA}(8 \mathrm{nM})$ binding sites by isoproterenol $\left(10^{-4}\right.$ to $\left.10^{-9} \mathrm{M}\right)$ in the presence of $0.1 \mathrm{mM} \mathrm{Gpp}(\mathrm{NH}) \mathrm{p}(\boldsymbol{n}$, normal LV; $₫$, failure LV) demonstrate a similar $K_{\mathrm{L}}$ for normal and failure animals. When these experiments were run in the absence of $\mathrm{Gpp}(\mathrm{NH}) \mathrm{p},(\bullet$, normal LV; $\bullet$, failure LV), a shift to the right in heart failure in comparison with the curves for normal dogs indicates a loss in high affinity sites.

stimulation of adenylate cyclase by $0.1 \mathrm{mM}$ isoproterenol and $0.1 \mathrm{mM} \mathrm{Gpp}(\mathrm{NH}) \mathrm{p}$ was significantly depressed, $P<0.01$, in LV failure $(135 \pm 17 \mathrm{pmol} \mathrm{cAMP} / \mathrm{min}$ per $\mathrm{mg}$ protein) compared with normal hearts $(662 \pm 123 \mathrm{pmol} \mathrm{cAMP} / \mathrm{min}$ per $\mathrm{mg}$ protein). Maximal stimulation of adenylate cyclase by $10 \mathrm{mM}$ sodium fluoride was significantly less in LV failure (244 \pm 50 pmol cAMP/ min per mg protein) as compared with normal hearts (744 104 $\mathrm{pmol} \mathrm{cAMP} / \mathrm{min}$ per mg protein) (Fig. 4).

A dose response curve for adenylate cyclase stimulation by isoproterenol with GTP $(0.1 \mathrm{mM})$ using a purified sarcolemma preparation is shown in Fig. 5. The maximal response was threefold higher in the normal LV.

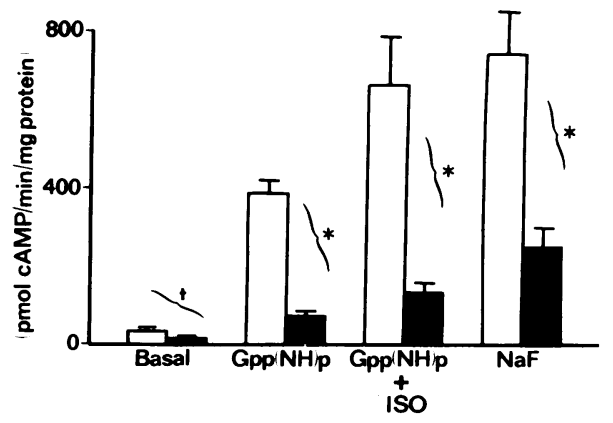

Figure 4. Basal adenylate cyclase activity (first panel), and maximal adenylate cyclase activity (mean \pm SEM) using $\mathrm{Gpp}(\mathrm{NH}) \mathrm{p}$ (second panel), $0.1 \mathrm{mM} \mathrm{GppNHp}$ plus $0.1 \mathrm{mM}$ isoproterenol (third panel), and $10 \mathrm{mM}$ sodium fluoride (fourth panel), are compared with normal controls ( $n=8$, open bars) and animals with heart failure $(n=9$, solid bars). There was a marked depression of maximal-stimulatable adenylate cyclase in LV failure. ${ }^{*} P<0.01 ; \dagger P<0.02$. 


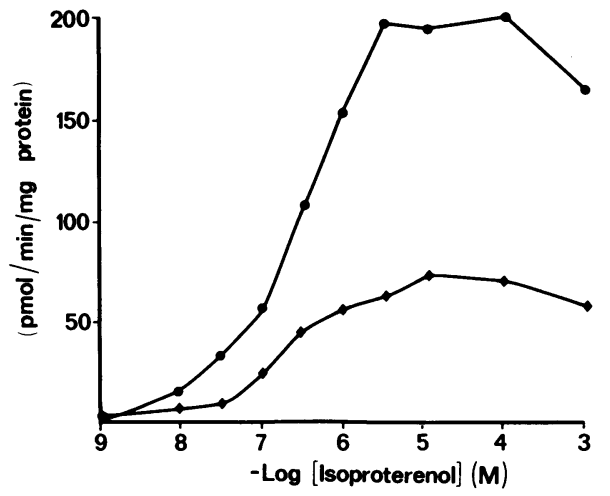

Figure 5. Isoproterenol-stimulated adenylate cyclase $\left(10^{-4}\right.$ to $\left.10^{-9} \mathrm{M}\right)$ in the presence of $0.1 \mathrm{mM}$ GTP are compared in the purified sarco-

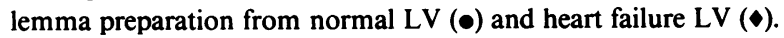
Basal activity with GTP for the normal LV is $255 \mathrm{pmol} \mathrm{cAMP} / \mathrm{min}$ per $\mathrm{mg}$ protein and for heart failure LV basal activity is $129 \mathrm{pmol} / \mathrm{min}$ per mg protein.

Other membrane markers. $\mathrm{Na}^{+}, \mathrm{K}^{+}$-ATPase activity of myocardial membranes, another membrane-associated protein that is uninvolved in ligand recognition, was used as a reference for the $\beta$-adrenergic receptor. The plasma membrane-associated activity of $\mathrm{Na}^{+}, \mathrm{K}^{+}$-ATPase was $2.8 \pm 0.1 \mu \mathrm{mol} \mathrm{P}_{\mathrm{i}} / \mathrm{h}$ per mg protein $(n=7)$ in the normal $\mathrm{LV}$. In $\mathrm{LV}$ failure preparations, $\mathrm{Na}^{+}, \mathrm{K}^{+}$ATPase activity was less, $2.0 \pm 0.2 \mu \mathrm{mol} \mathrm{P}_{\mathrm{i}} / \mathrm{h}$ per $\mathrm{mg}$ protein $(n$ $=6$ ). Thus, the increase in $\beta$-adrenergic receptor density in the LV failure membranes did not reflect an alteration in the membrane preparation between control and heart failure animals.

Norepinephrine levels. In the LV failure animals, LV tissue norepinephrine $(221 \pm 77 \mathrm{pg} / \mathrm{mg})$ was depressed $(P<0.02)(n$ $=6$ ) compared with $\mathrm{LV}$ values $(473 \pm 58 \mathrm{pg} / \mathrm{mg})$ in the nine normal dogs in which it was measured. Plasma norepinephrine was higher in the animals with LV failure (505 \pm 96 vs. $290 \pm 20 \mathrm{pg} /$ $\mathrm{ml})(P<0.05)$.

\section{Discussion}

Defects in autonomic regulation of the failing heart have been noted for some time $(2,3,17)$. The most frequent and impressive finding has been a reduction in catecholamine stores (18-20). This occurs in the hypertrophied heart (7), but is more severe in LV failure. In contrast, in chronic heart failure, plasma levels of norepinephrine are elevated (21). The present investigation indicates that several alterations in the $\beta$-adrenergic receptorcyclase system also occur in heart failure.

First, as with the state of hypertrophy before the development of $\mathrm{LV}$ decompensation (7), $\beta$-adrenergic receptor number increased, and a decreased affinity for $\left[{ }^{3} \mathrm{H}\right] \mathrm{DHA}$ was again apparent. Although the increase in receptor number could be a secondary adjustment to a depletion of local catecholamine stores, it is difficult to reconcile the persistent alteration in antagonist affinity. That this phenomenon is not some artifact of the binding procedure employed is underscored by our recent studies using identical biochemical techniques in the canine heart after chronic surgical denervation. In this model, we demonstrated that an increase in receptor number of similar magnitude occurs without any alteration in affinity for $\left[{ }^{3} \mathrm{H}\right] \mathrm{DHA}(10)$. These observations suggest that the receptor protein expressed in the left ventricle of animals with LV hypertrophy and failure may differ from those of normal animals, similar to the expression of new gene products for a variety of myocardial proteins, including myosin (22), creatine phosphokinase (23), and lactate dehydrogenase $(24,25)$, which occurs with the development of hypertrophy. Such a protein might have minor differences in its primary amino acid structure, possibly occurring within an epitope in the ligand binding site itself. Other studies of agonist binding and adenylate cyclase activity were conducted to examine whether the receptor protein expressed in the failing LV showed other features that distinguished it from the normal animal, particularly in relation to its coupling to adenylate cyclase.

Previous work has demonstrated that the $\beta$-adrenergic receptor can exist in two affinity states for agonists $(26,27)$. It is the high affinity form of the receptor that is functionally coupled to the GTP-stimulating protein $\left(N_{\mathrm{s}}\right)$, and thus has been considered to be the physiologically relevant form of the receptor. To determine which form of the receptor exists in the dogs with LV failure, agonist competition curves were generated in the presence and absence of $\mathrm{Gpp}(\mathrm{NH}) \mathrm{p}$. In the absence of guanylyl nucleotides, the curve is more shallow and can be modeled by two sites, $K_{\mathrm{L}}$ and $K_{\mathrm{H}}$, for isoproterenol. With the addition of $\mathrm{Gpp}(\mathrm{NH}) \mathrm{p}$, which converts all the receptors into $K_{\mathrm{L}}$, the curve shifts to the right, becomes steeper, and follows a typical mass action relationship for a single site of $K_{\mathrm{L}}$. Computer modeling of these curves demonstrated major differences between normal and failure animals. In Fig. 3, it is apparent that in the absence of $\mathrm{Gpp}(\mathrm{NH}) \mathrm{p}$, the competition curve generated with the membranes from failing hearts is steeper and shifted to the right when compared with the curves derived from normal hearts. The pooled experimental data indicate that only $11 \%$ of the total receptor population is in a "coupled" or high affinity state in the heart failure animals, as compared with $51 \%$ for the normal animals.

This finding of a decrease of $\beta$-adrenergic receptors in the high affinity state suggests that catecholamines have a reduced ability to trigger an appropriate inotropic response for any given number of agonist-occupied receptors in the hearts of animals with LV failure. This finding may be important in understanding the mechanism of depressed inotropic and chronotropic responses to sympathetic nerve activation in heart failure. Whereas prior studies have suggested that this was due to reduced innervation and catecholamine stores $(17,28)$, the current data would also implicate a postsynaptic mechanism.

It is possible that this alteration represents a state of receptor desensitization whereby an uncoupling of the receptor from the effector protein, $N_{\mathrm{s}}$, has been promoted (29). It is important to note, however, that the total receptor number was actually increased in heart failure in this study, a finding that would not have been predicted in a state of increased catecholamine exposure. Furthermore, this increase in receptor number was not a nonspecific effect observed with other membrane proteins, since $\mathrm{Na}^{+}, \mathrm{K}^{+}$-ATPase activity was not elevated in heart failure.

A second possible explanation for the loss in high affinity receptors is suggested by our finding that in heart failure the affinity of the receptor for $\left[{ }^{3} \mathrm{H}\right] \mathrm{DNA}$ is altered. As noted above, if the receptor protein itself were different, this may also be reflected in a decreased ability of the receptor to form a high affinity interaction with $N_{\mathrm{s}}$.

A third potential mechanism underlying the observed reduction in the fraction of high-affinity receptors in heart failure is a deficiency or abnormality of the GTP-coupling protein. So- 
dium fluoride and $\mathrm{Gpp}(\mathrm{NH}) \mathrm{p}$ both require $N_{\mathrm{s}}$ for cyclase stimulation. This finding of decreased cyclase activity together with a reduction in the number of high affinity or "coupled" receptors implies that $N_{\mathrm{s}}$ could be functionally deficient in the hearts of failure animals. Further inquiry into this possibility could be undertaken by the development of reconstitution protocols designed to assess the functional level of $N_{\mathrm{s}}$. Such an abnormality occurs in one form of pseudohypoparathyroidism, where a decreased concentration of high affinity agonist-binding sites in erythrocytes has been documented (30), as well as in certain other pathophysiological states such as hypothyroidism, $(31)$ or after adrenalectomy, (32) where abnormalities in $\beta$-adrenergic receptor function were found to occur with a decrease in the concentration of high-affinity agonist binding sites.

The muscarinic, cholinergic receptor, another plasma membrane-bound receptor, was studied to see if the changes in $\beta$ adrenergic receptor density were specific or if other receptors were altered in a similar manner. In contrast to the results for $\beta$-adrenergic receptor density, which rose, muscarinic receptor number was reduced by $50 \%$ in the $\mathrm{LV}$ with heart failure. It is possible that the decrease in muscarinic receptor density may be due to a loss of sympathetic prejunctional neurons in heart failure, resulting in a loss of associated muscarinic receptors located prejunctionally, as may occur with cardiac denervation (10). Again, it should be emphasized that the changes in muscarinic receptor density occurred in a direction opposite from the $\beta$-adrenergic receptor. Finally, it might be speculated that the decrease in muscarinic receptor density may be involved in the mechanism of altered parasympathetic control of the failing heart (1-3).

In summary, this study has demonstrated in a chronic canine model of LV hypertrophy and failure that an uncoupling of the $\beta$-receptor occurs, as evidenced by a decrease in the number of receptors that bind agonist with high affinity. Further evidence is provided to suggest that this is not the sole result of a desensitization process secondary to increased catecholamine exposure. Subsequent biochemical studies will be required to determine whether the receptor protein itself, the GTP-regulatory protein, or some other membrane component(s) is primarily responsible for the observed alterations in $\beta$-adrenergic receptor function.

\section{Acknowledgments}

We are grateful for the careful technical assistance provided by Michelle Connole, Twila Kenna, and Beth Mitchell. In particular, we acknowledge Dr. Kurt Schwarz's invaluable assistance with the computer modeling of our binding data. We thank Dr. A. Watanabe for his encouragement and advice.

This work was supported in part by U. S. Public Health Service grants HL 23724, 19259, and 31280, and RR0168, and a Grant-in-Aid from the American Heart Association, with funds contributed in part by the Massachusetts Affiliate No. 84-1139. Dr. Dorothy Vatner is currently supported by U. S. Public Health Service New Investigator Research Award HL 31280. Dr. Fujii is supported by National Institutes of Health Clinical Investigator Award HL 01452. Dr. Homcy is an Established Investigator of the American Heart Association.

\section{References}

1. Abboud, F. M., H. A. Fozzard, J. P. Gilmore, and D. J. Reis, editors. 1981. Disturbances in Neurogenic Control of the Circulation. Williams and Wilkins Company, Baltimore. 1-263.
2. Eckberg, D. L., M. Drabinsky, and E. Braunwald. 1971. Defective cardiac parasympathetic control in patients with heart disease. $N$. Engl. J. Med. 285:877-883.

3. Higgins, C. B., S. F. Vatner, D. L. Eckberg, and E. Braunwald. 1972. Alterations in the baroreceptor reflex in conscious dogs with heart failure. J. Clin. Invest. 51:715-724.

4. Karliner, J. S., P. Barnes, M. Brown, and C. Dollery. 1980. Chronic heart failure in the guinea pig increases cardiac $\alpha$ - and $\beta$-adrenoceptors. Eur. J. Pharmacol. 67:115-118.

5. Bristow, M. R., R. Ginsburg, W. Minobe, R. S. Cubicciotti, W. S. Sageman, K. Lurie, M. E. Billingham, D. C. Harrison, and E. B. Stinson. 1982. Decreased catecholamine sensitivity and $\beta$-adrenergicreceptor density in failing human hearts. $N$. Engl. J. Med. 307:205-211.

6. Jones, L. R., and H. R. Besch, Jr. 1984. Isolation of canine cardiac sarcolemmal vesicles. Methods Pharmacol. 5:1-12.

7. Vatner, D. E., C. J. Homcy, S. P. Sit, W. T. Manders, and S. F. Vatner. 1984. Effects of pressure overload, left ventricular hypertrophy on $\beta$-adrenergic receptors, and responsiveness to catecholamines. J. Clin. Invest. 73:1473-1482.

8. Stiles, G. L., M. G. Caron, and R. J. Lefkowitz. 1984. $\beta$-Adrenergic receptors: biochemical mechanisms of physiological regulation. Physiol. Rev. 64:661-743.

9. Munson, P. J., and D. Rodbard. 1980. Ligand: a versatile computerized approach for characterization of ligand-binding systems. Anal. Biochem. 107:220-239.

10. Vatner, D. E., M. Lavallee, J. Amano, A. Finizola, C. J. Homcy, and S. F. Vatner. 1985. Mechanisms of supersensitivity to sympathomimetic amines in the chronically denervated heart of the conscious dog. Circ. Res. 57:55-64.

11. Fields, J. Z., W. R. Roeske, E. Morkin, and H. I. Yamamura. 1978. Cardiac muscarinic cholinergic receptors: biochemical identification and characterization. J. Biol. Chem. 253:3251-3258.

12. Salomon, Y., C. Londos, and M. Rodbell. 1974. A highly sensitive adenylate cyclase assay. Anal. Biochem. 58:541-547.

13. Peuler, J., and G. Johnson. 1977. Simultaneous single isotope radioenzymatic assay of plasma norepinephrine, epinephrine, and dopamine. Life Sci. 21:625-636.

14. Lowry, O. H., N. J. Rosebrough, A. L. Farr, and R. J. Randall. 1951. Protein measurement with folin phenol reagent. J. Biol. Chem. 193:265-275.

15. Snedecor, G. W., and W. G. Cochran. 1968. Statistical Methods. lowa State University Press, Ames, lowa. 447-471.

16. Armitage, P. 1975. Statistical methods in Medical Research. Blackwell Scientific Press, London. 1-504.

17. Schmid, P. G., D. D. Lund, and R. R. Roskoski. 1981. Efferent autonomic dysfunction in heart failure. In Disturbances in Neurogenic Control of the Circulation. F. M. Abboud, H. A. Fozzard, J. P. Gilmore, and D. J. Reis, editors. American Physiological Society, Bethesda. 3349.

18. Chidsey, C. A., E. Braunwald, and A. G. Morrow. 1965. Catecholamine excretion and cardiac stores of norepinephrine in congestive heart failure. Am. J. Med. 39:442-451.

19. Gertler, M. M., E. Saluste, and F. Spencer. 1970. Biochemical analyses of human papillary muscles and guinea pig ventricles in failure. Proc. Soc. Exp. Biol. Med. 135:817-823.

20. Spann, J. F., C. A. Chidsey, P. E. Pool, and E. Braunwald. 1965. Mechanisms of norepinephrine depletion in experimental heart failure produced by aortic constriction in the guinea pig. Circ. Res. 17:312321.

21. Francis, G. S., S. R. Goldsmith, and J. N. Cohn. 1982. Relationship of exercise capacity to resting left ventricular performance and basal plasma norepinephrine levels in patients with congestive heart failure. Am. Heart J. 104:725-731.

22. Lompre, A., D. Schwartz, A. D'Albis, G. Lacombe, N. Van Thien, and B. Swynghedauw. 1979. Myosin isoenzyme redistribution in chronic heart overload. Nature (Lond.). 282:105-107.

23. Vatner, D. E., S. F. Vatner, S. P. Sit, and J. S. Ingwall. 1982. 
Alteration of creatine kinase and its isozymes in response to pressure overload. Physiologist. 25:191.

24. Fox, A. C., and G. E. Reed. 1969. Changes in lactate dehydrogenase composition of hearts with right ventricular hypertrophy. Am.J. Physiol. 216:1026-1033.

25. York, J. W., D. G. Penney, T. A. Weeks, and P. A. Stagno. 1976. Lactate dehydrogenase changes following several cardiac hypertrophic stresses. J. Appl. Physiol. 40:923-926.

26. Manalan, A. S., H. R. Besch, and A. M. Watanabe. 1981. Characterization of $\left[{ }^{3} \mathrm{H}\right]( \pm)$ carazolol binding to $\beta$-adrenergic receptors. Application to study of $\beta$-adrenergic receptor subtypes in canine ventricular myocardium and lung. Circ. Res. 49:326-336.

27. DeLean, A., J. M. Stadel, and R. J. Lefkowitz. 1980. A ternary complex model explains the agonist-specific binding properties of the adenylate cyclase-coupled $\beta$-adrenergic receptor. J. Biol. Chem. 255: 7108-7117.
28. Covell, J. W., C. A. Chidsey, and E. Braunwald. 1966. Reduction of cardiac response to postganglionic sympathetic nerve stimulation in experimental heart failure. Circ. Res. 19:51-56.

29. Harden, T. K. 1983. Agonist-induced desensitization of the $\beta$ adrenergic receptor-linked adenylate cyclase. Pharmacol. Rev. 35:5-32.

30. Heinsimer, J. A., A. O. Davies, R. W. Downs, M. A. Levine, A. M. Spiegel, M. K. Drezner, A. DeLean, K. A. Wreggett, M. G. Caron, and R. J. Lefkowitz. 1984. Impaired formation of $\beta$-adrenergic receptornucleotide regulatory protein complexes in pseudohypoparathyroidism. J. Clin. Invest. 73:1335-1343.

31. Stiles, G. L., J. M. Stadel, A. DeLean, and R. J. Lefkowitz. 1981. Hypothyroidism modulates beta adrenergic receptor-adenylate cyclase interactions in rat reticulocytes. J. Clin. Invest. 68:1450-1455.

32. Davies, A. O., A. DeLean, and R. J. Lefkowitz. 1981. Myocardial $\beta$-adrenergic receptors from adrenalectomized rats: impaired formation of high-affinity agonist-receptor complexes. Endocrinology. 108:720-722. 